\title{
Efficacy of Seed Treatment Chemicals for Black Root Rot, Caused by Thielaviopsis basicola, on Cotton
}

\author{
Harun Toksoz and Craig S. Rothrock, Department of Plant Pathology, University of Arkansas, Fayetteville 72701; \\ and Terrence L. Kirkpatrick, Southwest Research and Extension Center, University of Arkansas, Hope 71801
}

\begin{abstract}
Toksoz, H., Rothrock, C. S., and Kirkpatrick, T. L. 2009. Efficacy of seed treatment chemicals for black root rot, caused by Thielaviopsis basicola, on cotton. Plant Dis. 93:354-362.

The efficacy of triazole and host resistance-inducing seed treatment chemicals was examined for black root rot on cotton caused by Thielaviopsis basicola in both artificially and naturally infested soils with and without nematodes. In naturally infested soil, myclobutanil was effective in reducing root and hypocotyl discoloration over a wide range of soil population densities. Treatments containing high rates $(42 \mathrm{~g}$ a.i./100 $\mathrm{kg}$ seed) of myclobutanil provided greater reductions in disease than low rates $(21 \mathrm{~g}$ a.i./100 kg seed) in some experiments. Acibenzolar- $S$-methyl applied to the seed reduced black root rot or colonization by T. basicola on seedlings in artificially infested soils. Rates of acibenzolar-S-methyl did not differ in efficacy. In controlled studies, root colonization by $T$. basicola was significantly lower when seeds were treated with both myclobutanil and acibenzolar-S-methyl than with either chemical alone. In naturally infested soil under low (24 CFU/g soil) and high (154 CFU/g soil) populations of T. basicola, a combination of myclobutanil and acibenzolar- $S$-methyl at the high rate resulted in the lowest root discoloration and colonization. The nematicide seed treatment abamectin improved the control of black root rot in the presence of Meloidogyne incognita. The semi-selective medium TB-CEN allowed the importance of T. basicola to be evaluated in the presence of other pathogens that contribute to the seedling disease complex on cotton by quantifying the isolation frequency and percent colonization of $T$. basicola.
\end{abstract}

Thielaviopsis basicola (Berk. \& Broome) Ferraris (syn. Chalara elegans Nag Raj \& Kendrick) was first reported on cotton as causing a collar rot of mature cotton plants (Gossypium barbadense L.) in late summer or early fall in Sacaton, AZ as early as 1922 (15,16). T. basicola was later found to cause a root rot on cotton seedlings of G. barbadense and Gossypium hirsutum L. (16,27). Currently, T. basicola is recognized as an economically important seedling pathogen of cotton throughout the world $(1,11)$. The fungus has a host range of over 230 species and is a destructive pathogen on the roots of many crop and ornamental plants (26).

The fungus causes a cortical root rot of cotton seedlings starting as early as 10 to 14 days after planting $(11,20)$. Gomaa (10) could not isolate $T$. basicola from cotton seedlings until the fifth day after planting and found that isolation increased dramatically between 5 and 10 days after planting. The fungus causes a dark-brown to black discoloration of the roots and hypocotyl, resulting in stunted, less vigorous seed-

Corresponding author: Craig Rothrock

E-mail: Rothrock@uark.edu

Accepted for publication 12 December 2008.

doi:10.1094/PDIS-93-4-0354

(C) 2009 The American Phytopathological Society lings and delayed flowering or maturity (1). Black root rot is most severe early in the growing season when soil temperatures are below $24^{\circ} \mathrm{C}$ and soil water content is high (25). As soil temperatures increase and the plants develop, the diseased cortical tissues slough off and secondary root growth occurs $(19,20)$.

T. basicola may interact synergistically with M. incognita on cotton (29-31). A significant increase in seedling death and a decrease in plant growth and yield occurred in microplots infested with both pathogens compared to plants grown in microplots infested with either pathogen alone. In histological observations, infection of cotton roots by the root-knot nematode allowed T. basicola to colonize vascular tissues, which are not normally colonized in $G$. hirsutum in the absence of the nematode (30).

There are limited management options for the control of black root rot. Crop rotation can reduce $T$. basicola populations $(12,23)$; however, extended rotations are rarely practiced by cotton producers. No resistant cultivars are available for black root rot on cotton $(32,33)$. Seed treatment fungicides are nearly universally used on cotton for the control of various pathogens in the seedling disease complex. However, the extent of control of black root rot with these fungicide seed treatments is unknown. Myclobutanil (6) and triadimenol (4), two triazole fungicides, have been shown to have some efficacy for the control of black root rot. The rates of these fungicides used on cotton, however, are directed at the control of Rhizoctonia solani and are generally not used at rates considered sufficient to provide significant control of $T$. basicola. Recently, acibenzolar-S-methyl (Bion), one of the systemic acquired resistance (SAR) chemical inducers, has been shown to reduce black root rot on cotton (21) and was registered recently for cotton in Australia.

The objective of this study was to evaluate the efficacy of seed treatment chemicals, including fungicides and host resistance inducers, individually and in combination for controlling black root rot on cotton. The efficacy of seed treatments was examined in both artificially and naturally infested soils with and without nematodes due to the synergistic interaction between $T$. basicola and M. incognita.

\section{MATERIALS AND METHODS}

Cottonseed, not treated and treated with appropriate pesticides, were supplied by D. H. Long (Syngenta Crop Protection, Greensboro, NC). The cotton cultivars DP 444 BG/RR or DP 555 BG/RR (Delta and Pineland, Scott, MS) were used in these studies. All seed also were treated with $\mathrm{CaCO}_{3}$ (198.44 g/100 kg seed), polymer (Secure $28.34 \mathrm{~g} / 100 \mathrm{~kg}$ seed, Becker Underwood, Ames, IA), and dye (Color Coat Blue $28.34 \mathrm{~g} / 100 \mathrm{~kg}$ seed, Becker Underwood), standard components of a seed treatment combination on cotton to neutralize acid-delinted cottonseed and color the seed to indicate the presence of pesticides on the seed.

In addition to the seed treatments evaluated, seed were often treated with chemicals important in managing other seedling pathogens, early-season insects, or nematodes. The base seed treatment fungicides used in this study included fludioxonil (Maxim 4 FS), mefenoxam (Apron XL), and azoxystrobin (Dynasty). In addition to base seed treatment fungicides, custom seed treatment fungicides were azoxystrobin + fludioxonil + mefenoxam (Dynasty CST). The insecticide seed treatment was thiamethoxam (Cruiser). The nematicide seed treatment was abamectin (Avicta). Aldicarb (Temik 840 g/ha; Bayer CropScience, Research Triangle Park, NC) was included as an in-furrow treatment for thrips and nematodes in the field study. Seed treatment fungicides examined for 
their efficacy against $T$. basicola were myclobutanil (Systhane) and acibenzolar$S$-methyl (Bion).

T. basicola inoculum was prepared using the isolate $3 \mathrm{~N}-25 \mathrm{~B}$ recovered from cotton seedlings at the Delta Branch Station near Clarkdale, AR. Individual chlamydospores were prepared as described by Candole and Rothrock (8). Briefly, 6week-old cultures of $T$. basicola grown on $10 \%$ carrot juice agar were flooded with sterile distilled water and decanted repeatedly to dislodge endoconidia. The chlamydospores along with the remaining endoconidia and hyphae were scraped from the surface of the cultures with a rubber policeman, suspended in sterile distilled water, and passed through a monofilament nylon fabric with 53- $\mu \mathrm{m}$ openings (Tetko, Inc., Depew, NY). The suspension was then filtered through a monofilament nylon fabric with $20-\mu \mathrm{m}$ openings and was rinsed with sterile distilled water to remove endoconidia. Chlamydospore chains retained on the nylon fabric were scraped off with a spatula into a sterile $15-\mathrm{ml}$ centrifuge tube containing about $50 \mathrm{mg}$ of 212 to $300 \mu \mathrm{m}$ diameter glass microbeads. To digest chlamydospore chains, 12.5 units of chitinase from Streptomyces griseus (Sigma Chemical Co., St. Louis, MO) in $1 \mathrm{ml}$ of buffer was added to the centrifuge tube with $12 \mathrm{ml}$ of sterile distilled water. The suspension was placed on a shaker at 75 cycles per minute at $37^{\circ} \mathrm{C}$ for $24 \mathrm{~h}$ and then vortexed at high speed for $2 \mathrm{~min}$. Chlamydospore chain separation was confirmed by microscopic examination, and the mixture was poured through nylon fabric with $20-\mu \mathrm{m}$ openings. After several washings with a minimal volume of sterile distilled water, the filtrate was collected and centrifuged. The chlamydospores were resuspended in sterile distilled water and centrifuged three times to remove the chitinase. Chlamydospores were resuspended in sterile distilled water and stored in a refrigerator at 2 to $5^{\circ} \mathrm{C}$. Chlamydospore viability, percent germination, was determined before each experiment by plating spores on carrot juice agar.

Soil populations for artificially and naturally infested experiments were determined for $T$. basicola by the pour-plate technique using the semi-selective medium TB-CEN (28) amended with Penicillin G, $60 \mathrm{mg} /$ liter (ICN Biomedicals Inc., Auroro, $\mathrm{OH})$. Twenty-seven grams of soil was suspended in sufficient sterile $0.15 \%$ water agar to make $250 \mathrm{ml}$. The sample was shaken on a wrist action shaker for $20 \mathrm{~min}$ prior to assaying populations. One milliliter of soil suspension was pipetted into each petri plate $(100 \times 15 \mathrm{~mm})$. Twentyseven to thirty milliliters of molten medium $\left(\sim 45^{\circ} \mathrm{C}\right)$ was then poured into each plate, and plates were swirled to uniformly distribute the soil suspension. Ten plates were used for each soil sample. Plates were kept at room temperature (20 to $22^{\circ} \mathrm{C}$ ) in the dark for 14 days prior to counting colonies growing on the medium. Counts were adjusted to colony forming units per gram of soil based on soil oven dry weight (odw).

The population of $M$. incognita used was collected from an infested field in Drew County, AR, and increased on tomato (Lycopersicon esculentum L. cv. Rutgers) in a greenhouse at the University of Arkansas Southwest Research and Extension Center at Hope, AR. Nematode eggs and juveniles were extracted from infected tomato roots using $0.5 \% \mathrm{NaOCl}$ for $2 \mathrm{~min}$ as described by Hussey and Barker (13).

Soil samples from sites naturally infested with $T$. basicola were sent to the Arkansas Nematode Diagnostic Clinic Laboratory, University of Arkansas Southwest Research and Extension Center, to determine nematode populations. Nematodes were extracted from the samples using a semi-automatic elutriator (7) followed by centrifugal flotation (14), and nematodes were quantified with a stereoscope at $\times 40$ to 60 magnification.

Experiments in artificially infested soil. A Rilla silt loam soil (40\% sand, $56 \%$ silt, and $4 \%$ clay) from a field known to be infested with $T$. basicola and $M$. incognita was utilized in this study. The soil was pasteurized for $0.5 \mathrm{~h}$ at $70^{\circ} \mathrm{C}$ prior to infestation.

A controlled-environment experiment was conducted to examine the efficacy of myclobutanil and acibenzolar- $S$-methyl alone and in combination for black root rot control. Four different seed treatment combinations, including no seed treatment, were used in this experiment (Table 1). The soil was infested with 60 viable chlamydospores of $T$. basicola per gram by diluting inoculum in $50 \mathrm{ml}$ of deionized water and mixing the suspension into soil
$(12,800 \mathrm{~g}$ of soil odw $)$ for each tub $(40 \times$ $25 \times 13 \mathrm{~cm}$ ). Fourteen seed of the cotton cultivar DP 555 BG/RR were planted per treatment in a tub. The experiment had four replications and was conducted twice.

A separate controlled-environment experiment was conducted in the presence and absence of $T$. basicola and $M$. incognita in growth chambers. The soil in each tub $(12,800 \mathrm{~g}$ odw) was infested with 100 viable chlamydospores of $T$. basicola per gram of soil, 16 eggs or juveniles of $M$. incognita per gram of soil, both pathogens, or not infested. Soil was infested with $M$. incognita after planting by applying inoculum to the surface of the soil in $250 \mathrm{~cm}^{3}$ of water using a watering container. Eleven different seed treatment combinations (subplots) were used in this study (Table 2). Eight seed of the cotton cultivar DP 444 BG/RR were planted per treatment in each tub. The experiment was a randomized complete block split-plot design with four replications, and the experiment was conducted twice.

For controlled-environment experiments, tubs were placed into growth chambers with a diurnal temperature regime of $15^{\circ} \mathrm{C}$ night and $24^{\circ} \mathrm{C}$ day, temperatures typical of the soil temperatures early in the growing season (22), with a 14-h photoperiod. The average light intensity for this study was $207 \mu \mathrm{mol} / \mathrm{m}^{2} / \mathrm{s}$, ranging from 130 to $288 \mu \mathrm{mol} / \mathrm{m}^{2} / \mathrm{s}$. Tubs were watered every other day. An additional set of experiments for the fourtreatment study was conducted in the greenhouse. For this study, soil temperatures averaged $25^{\circ} \mathrm{C}$ day and $19^{\circ} \mathrm{C}$ night. The average light intensity at noon on a sunny day was $503 \mu \mathrm{mol} / \mathrm{m}^{2} / \mathrm{s}$, ranging from 441 to $630 \mu \mathrm{mol} / \mathrm{m}^{2} / \mathrm{s}$. Experiments were terminated 28 days after planting.

Plants were removed from the tubs, washed under running tap water to remove

Table 1. Efficacy of myclobutanil and acibenzolar-S-methyl seed treatments on black root rot in artificially infested soil in the growth chamber ${ }^{\mathrm{v}}$

\begin{tabular}{|c|c|c|c|c|c|}
\hline Treatments & $\begin{array}{l}\text { Rate (g a.i./ } \\
100 \mathrm{~kg} \text { seed) }\end{array}$ & $\begin{array}{l}\text { Root discolor- } \\
\text { ation }(\%)^{\mathrm{w}}\end{array}$ & $\begin{array}{l}\text { Hypocotyl } \\
\text { lesions }(\%)^{x}\end{array}$ & $\begin{array}{c}\text { Colonization } \\
(\%)^{\mathrm{y}}\end{array}$ & $\begin{array}{c}\text { Isolation } \\
(\%)\end{array}$ \\
\hline Nontreated & $\ldots$ & $35.1 \mathrm{~A}^{\mathrm{z}}$ & $68.9 \mathrm{~A}$ & $87.3 \mathrm{~A}$ & $100.0 \mathrm{~A}$ \\
\hline Acibenzolar- $S-n$ & 1 & $12.5 \mathrm{~B}$ & $37.3 \mathrm{~B}$ & $49.0 \mathrm{~B}$ & $91.7 \mathrm{AB}$ \\
\hline Myclobutanil & 21 & $6.5 \mathrm{BC}$ & $11.5 \mathrm{C}$ & $27.4 \mathrm{C}$ & $82.3 \mathrm{~B}$ \\
\hline $\begin{array}{l}\text { Acibenzolar- } S \text {-methyl }+ \\
\text { myclobutanil }\end{array}$ & $1+21$ & $2.4 \mathrm{C}$ & $3.3 \mathrm{C}$ & $25.9 \mathrm{C}$ & $84.3 \mathrm{~B}$ \\
\hline$P$ value & & $<0.0001$ & $<0.0001$ & $<0.0001$ & 0.0047 \\
\hline
\end{tabular}

${ }^{v}$ Experiments were conducted in a growth chamber with average temperatures of $24^{\circ} \mathrm{C}$ day and $15^{\circ} \mathrm{C}$ night and light intensity of $207 \mu \mathrm{mol} / \mathrm{m}^{2} / \mathrm{s}$.

${ }^{\text {w }}$ Root discoloration was assessed on a 0 to 10 scale, where $0=0 \%, 1=1-10 \%, 2=11-20 \%, 3=21$ $30 \%, 4=31-40 \%, 5=41-50 \%, 6=51-60 \%, 7=61-70 \%, 8=71-80 \%, 9=81-90 \%$, and $10=91$ $100 \%$ of the root system discolored. Analyses were conducted on mid-percentile values.

${ }^{\mathrm{x}}$ Hypocotyl discoloration was assessed on a 1 to 4 scale, where $1=$ healthy, $2=$ slight discoloration, 3 $=$ lesions, and $4=$ girdling lesions. Percentages of plants having hypocotyl lesions, ratings of 3 or 4 , were analyzed and presented.

y Colonization was assessed by a 0 to 10 scale, where $0=0 \%, 1=1-10 \%, 2=11-20 \%, 3=21-30 \%, 4$ $=31-40 \%, 5=41-50 \%, 6=51-60 \%, 7=61-70 \%, 8=71-80 \%, 9=81-90 \%$, and $10=91-100 \%$ of the root system having growth of T. basicola on the medium. Analyses were conducted on mid-percentile values.

${ }^{z}$ Combined data from two experiments. Means in a column followed by a common letter are not significantly different, protected LSD $(P \leq 0.05)$. 
soil, blotted dry, and weighed. The numbers of nodes above the cotyledonary node and plant weights were recorded for all plants. Root discoloration was rated by using a scale of 0 to 10 , in which $0=0 \%$, $1=1$ to $10 \%, 2=11$ to $20 \%, 3=21$ to $30 \%, 4=31$ to $40 \%, 5=41$ to $50 \%, 6=51$ to $60 \%, 7=61$ to $70 \%, 8=71$ to $80 \%, 9=$ 81 to $90 \%$, and $10=91$ to $100 \%$ of the root system discolored. Hypocotyl discoloration was rated on a scale of 1 to 4 , in which $1=$ healthy, 2 = slight discoloration, $3=$ lesions, and 4 = girdling lesions. Galling associated with the root-knot nematode was evaluated for a root system on a scale of 1 to 6 , with $1=$ no galls, $2=1$ to 2 galls, $3=3$ to 10 galls, $4=11$ to 30 galls, $5=31$ to 99 galls, and $6=$ galls $\geq 100$.

After disease evaluation, roots were disinfested in $0.5 \% \mathrm{NaOCl}$ for $1.5 \mathrm{~min}$, blot- ted dry on a paper towel, and plated on the amended TB-CEN medium. Plates were kept at room temperature $\left(20\right.$ to $\left.22^{\circ} \mathrm{C}\right)$ in the dark. Roots were observed at 7 to 10 days on TB-CEN medium and rated using a 0 to 10 scale similar to the root discoloration scale for percent $T$. basicola colonization, the percentage of the root system with growth of $T$. basicola on the medium.

Experiments in naturally infested soil. Controlled-environment experiments were conducted to evaluate the efficacy of seed treatment chemicals to control the black root rot pathogen, $T$. basicola, in naturally infested soils. Field soils were selected that differed in soil populations of T. basicola and the presence of plant parasitic nematodes.

Three soils from different locations were used in this study: (i) soil infested with $T$. basicola (24 CFU/g soil) and Rotylenchu- lus reniformis, reniform nematode, from a field near St. Charles, AR, (ii) soil infested with $T$. basicola (68 CFU/g soil) from a field near Trumann, AR, and (iii) soil infested with T. basicola (154 or $162 \mathrm{CFU} / \mathrm{g}$ soil) and $M$. incognita from a field near Portland, AR. Soil texture for each location was determined using the hydrometer particle-size method (3): (i) a silt loam soil ( $26.4 \%$ sand, $58 \%$ silt, $15.6 \%$ clay), (ii) a loamy sand soil $(70.4 \%$ sand, $26 \%$ silt, $3.6 \%$ clay), and (iii) a sandy loam soil (58.4\% sand, $40 \%$ silt, $1.6 \%$ clay), respectively. Soils were collected on 20 May 2007, 15 October 2007, and 15 October 2007 or 9 May 2008 for the St. Charles, Trumann, and Portland fields, respectively, and were refrigerated at 2 to $5^{\circ} \mathrm{C}$ prior to use.

Six different seed treatment combinations were used (Table 3). Six seed of the

Table 2. Efficacy of seed treatment combinations on black root rot in soils artificially infested with Thielaviopsis basicola

\begin{tabular}{|c|c|c|c|c|c|}
\hline Treatments $^{\mathrm{v}}$ & Rate (g a.i./100 kg) & Root discoloration $(\%)^{\mathrm{w}}$ & Hypocotyl lesions $(\%)^{x}$ & Colonization $(\%)^{\mathrm{y}}$ & Isolation (\%) \\
\hline Nontreated & $\ldots$ & $53.0 \mathrm{~A}^{\mathrm{z}}$ & $63.3 \mathrm{~A}$ & $55.6 \mathrm{AB}$ & $94.3 \mathrm{~A}$ \\
\hline Seed treatment & & $45.8 \mathrm{ABC}$ & $66.2 \mathrm{~A}$ & $38.3 \mathrm{BCD}$ & $88.7 \mathrm{~A}$ \\
\hline Myclobutanil & 21 & $33.4 \mathrm{BCD}$ & $20.0 \mathrm{~B}$ & $31.1 \mathrm{CD}$ & $90.0 \mathrm{~A}$ \\
\hline Acibenzolar- $S$-methyl & 0.3 & $40.5 \mathrm{BCD}$ & $50.0 \mathrm{AB}$ & 46.7 ABC & $90.0 \mathrm{~A}$ \\
\hline Acibenzolar-S-methyl & 0.6 & $28.2 \mathrm{DE}$ & $39.1 \mathrm{AB}$ & $38.7 \mathrm{BCD}$ & $88.3 \mathrm{~A}$ \\
\hline Acibenzolar-S-methyl & 0.9 & $32.5 \mathrm{CD}$ & $37.5 \mathrm{AB}$ & $30.7 \mathrm{CD}$ & $87.5 \mathrm{~A}$ \\
\hline Abamectin + myclobutanil & $208.04+21$ & $14.1 \mathrm{E}$ & $20.0 \mathrm{~B}$ & $21.6 \mathrm{D}$ & $80.0 \mathrm{~A}$ \\
\hline Abamectin + acibenzolar- $S$-methyl & $208.04+0.3$ & 47.1 ABC & $58.1 \mathrm{~A}$ & $45.0 \mathrm{BC}$ & $92.5 \mathrm{~A}$ \\
\hline Abamectin + acibenzolar- $S$-methyl & $208.04+0.6$ & $48.6 \mathrm{ABC}$ & $50.6 \mathrm{AB}$ & $47.0 \mathrm{ABC}$ & $85.0 \mathrm{~A}$ \\
\hline Abamectin + acibenzolar- $S$-methyl & $208.04+0.9$ & $34.1 \mathrm{BCD}$ & $50.0 \mathrm{AB}$ & $29.8 \mathrm{CD}$ & $78.9 \mathrm{~A}$ \\
\hline Abamectin & 208.04 & $48.9 \mathrm{AB}$ & $57.5 \mathrm{~A}$ & $64.4 \mathrm{~A}$ & $91.2 \mathrm{~A}$ \\
\hline$P$ value & & $<0.0001$ & 0.0202 & 0.0005 & 0.7882 \\
\hline
\end{tabular}

${ }^{u}$ Experiments were conducted in a growth chamber with average temperatures of $24{ }^{\circ} \mathrm{C}$ day and $15^{\circ} \mathrm{C}$ night and light intensity of $207 \mu \mathrm{mol} / \mathrm{m}^{2} / \mathrm{s}$.

${ }^{v}$ All seed treated with azoxystrobin + fludioxonil + mefenoxam (Dynasty CST, $41.60 \mathrm{~g}$ a.i./100 kg seed), except nontreated.

${ }^{w}$ Root discoloration was assessed on a 0 to 10 scale, where $0=0 \%, 1=1-10 \%, 2=11-20 \%, 3=21-30 \%, 4=31-40 \%, 5=41-50 \%, 6=51-60 \%, 7=61-$ $70 \%, 8=71-80 \%, 9=81-90 \%$, and $10=91-100 \%$ of the root system discolored. Analyses were conducted on mid-percentile values.

${ }^{\mathrm{x}}$ Hypocotyl discoloration was assessed on a 1 to 4 scale, where $1=$ healthy, $2=$ slight discoloration, $3=$ lesions, and $4=$ girdling lesions. Percentages of plants having hypocotyl lesions, ratings of 3 or 4 , were analyzed and presented.

y Colonization was assessed on a 0 to 10 scale, where $0=0 \%, 1=1-10 \%, 2=11-20 \%, 3=21-30 \%, 4=31-40 \%, 5=41-50 \%, 6=51-60 \%, 7=61-70 \%, 8=71-$ $80 \%, 9=81-90 \%$, and $10=91-100 \%$ of the root system having growth of $T$. basicola on the medium. Analyses were conducted on mid-percentile values.

${ }^{\mathrm{z}}$ Combined data from two experiments. Means in a column followed by a common letter are not significantly different, protected LSD $(P \leq 0.05)$.

Table 3. Efficacy of seed treatments for the control of black root rot in soil naturally infested with low Thielaviopsis basicola populations ${ }^{\mathrm{t}}$

\begin{tabular}{|c|c|c|c|c|c|c|c|}
\hline \multirow[b]{2}{*}{ Treatments } & \multirow{2}{*}{$\begin{array}{c}\text { Rate } \\
\text { (g a.i./100 kg) }\end{array}$} & \multicolumn{2}{|c|}{ Root discoloration $(\%)^{\mathrm{u}}$} & \multirow{2}{*}{$\begin{array}{l}\text { Hypocotyl } \\
\text { lesions }(\%)^{\mathrm{v}}\end{array}$} & \multirow[b]{2}{*}{ Nodes } & \multirow{2}{*}{$\begin{array}{c}\text { Colonization } \\
(\%)^{\mathrm{w}}\end{array}$} & \multirow{2}{*}{$\begin{array}{l}\text { Isolation } \\
(\%)\end{array}$} \\
\hline & & Exp. 1 & Exp. 2 & & & & \\
\hline Base seed treatment ${ }^{\mathrm{x}}$ & & $29.4 \mathrm{~A}^{\mathrm{y}}$ & $38.1 \mathrm{~A}$ & $22.9 \mathrm{~A}$ & $2.1 \mathrm{~A}$ & $60.3 \mathrm{~A}$ & $91.6 \mathrm{~A}$ \\
\hline Myclobutanil ${ }^{\mathrm{X}, \mathrm{Z}}$ & 21 & $18.1 \mathrm{~B}$ & $30.7 \mathrm{AB}$ & $11.1 \mathrm{BC}$ & $2.2 \mathrm{~A}$ & $41.4 \mathrm{~B}$ & $86.8 \mathrm{~A}$ \\
\hline Myclobutanil + abamectin ${ }^{\mathrm{x}, \mathrm{z}}$ & $42+208.04$ & $31.1 \mathrm{~A}$ & $21.1 \mathrm{BCD}$ & $9.3 \mathrm{BC}$ & $2.3 \mathrm{~A}$ & $51.1 \mathrm{AB}$ & $91.3 \mathrm{~A}$ \\
\hline $\begin{array}{l}\text { Myclobutanil }+ \text { abamectin }+ \\
\text { acibenzolar- } S \text {-methyl } 1^{\mathrm{x}, \mathrm{z}}\end{array}$ & $21+208.04+0.6$ & $16.2 \mathrm{BC}$ & $23.4 \mathrm{BC}$ & $13.6 \mathrm{AB}$ & $2.3 \mathrm{~A}$ & $37.4 \mathrm{~B}$ & $81.4 \mathrm{~A}$ \\
\hline $\begin{array}{l}\text { Myclobutanil }+ \text { abamectin }+ \\
\text { acibenzolar- } S \text {-methyl }{ }^{\mathrm{x}, \mathrm{z}}\end{array}$ & $21+208.04+1.0$ & $22.1 \mathrm{AB}$ & $17.2 \mathrm{CD}$ & $7.4 \mathrm{BC}$ & $2.2 \mathrm{~A}$ & $41.7 \mathrm{~B}$ & $85.3 \mathrm{~A}$ \\
\hline $\begin{array}{l}\text { Myclobutanil }+ \text { abamectin }+ \\
\text { acibenzolar- } S \text {-methyl } \mathrm{l}^{\mathrm{x}, \mathrm{z}}\end{array}$ & $42+208.04+1.0$ & $7.9 \mathrm{C}$ & $11.1 \mathrm{D}$ & $0 \mathrm{C}$ & $2.2 \mathrm{~A}$ & $13.7 \mathrm{C}$ & $58.7 \mathrm{~B}$ \\
\hline$P$ value & & $<0.0001$ & $<0.0001$ & 0.0055 & 0.6395 & $<0.0001$ & $<0.0001$ \\
\hline
\end{tabular}

${ }^{t}$ Soil had a population of T. basicola of $24 \mathrm{CFU} / \mathrm{g}$ soil. Experiments were conducted in a growth chamber with average temperatures of $24^{\circ} \mathrm{C}$ day and $15^{\circ} \mathrm{C}$ night and light intensity of $207 \mu \mathrm{mol} / \mathrm{m}^{2} / \mathrm{s}$.

u Root discoloration was assessed on a 0 to 10 scale, where $0=0 \%, 1=1-10 \%, 2=11-20 \%, 3=21-30 \%, 4=31-40 \%, 5=41-50,6=51-60 \%, 7=61-70 \%$, $8=71-80,9=81-90 \%$, and $10=91-100 \%$ of the root system discolored. Analyses were conducted on mid-percentile values.

${ }^{\mathrm{v}}$ Hypocotyl discoloration was assessed on a 1 to 4 scale, where $1=$ healthy, $2=$ slight discoloration, $3=$ lesions, and $4=$ girdling lesions. Percentages of plants having hypocotyl lesions, ratings of 3 or 4 , were analyzed and presented.

${ }^{\text {w }}$ Colonization was assessed on a 0 to 10 scale, where $0=0 \%, 1=1-10 \%, 2=11-20 \%, 3=21-30 \%, 4=31-40 \%, 5=41-50,6=51-60 \%, 7=61-70 \%, 8=$ $71-80,9=81-90 \%$, and $10=91-100 \%$ of the root system having growth of $T$. basicola on the medium. Analyses were conducted on mid-percentile values.

${ }^{x}$ Seed treated with thiamethoxam + mefenoxam + fludioxonil $(471.56+7.5+2.5 \mathrm{~g}$ a.i. $/ 100 \mathrm{~kg} \mathrm{seed})$.

${ }^{y}$ Combined data from two experiments, except when presented separately. Means in a column followed by a common letter are not significantly different, protected LSD $(P \leq 0.05)$.

${ }^{\mathrm{z}}$ Seed treated with azoxystrobin + fludioxonil + mefenoxam (Dynasty CST, $41.60 \mathrm{~g}$ a.i. $/ 100 \mathrm{~kg}$ seed). 
cotton cultivar DP 444 BG/RR were planted in $10.5 \mathrm{~cm}$ diameter by $7.5 \mathrm{~cm}$ pots that contained approximately $450 \mathrm{~g}$ of soil (odw). Pots were arranged in a randomized complete block design (5 replications) and placed into growth chambers under the environmental conditions stated earlier. Pots were watered every other day. Experiments were terminated 28 days after planting. Plant growth and disease ratings were recorded as described previously. Experiments were conducted twice for each soil.

A field experiment was conducted to evaluate the efficacy of seed treatment chemicals in controlling the black root rot pathogen, T. basicola, and the root-knot nematode near Portland, AR in 2007. The field had a history of cotton production and severe damage from the root-knot nematode and seedling diseases, including black root rot. The field was treated with 28 liter/ha of 1,3-dichloropropene (Telone II, Dow AgroSciences, Indianapolis, IN) prior to planting. Eight different seed treatment combinations of the cotton cultivar DP $444 \mathrm{BG} / \mathrm{RR}$ were evaluated in this study (Table 4). The field was planted on 8 May 2007 at $3 \mathrm{seed} / 30 \mathrm{~cm}$ of row. Plot size was 6 rows by $30 \mathrm{~m}$ long with a $0.97-\mathrm{m}$ row spacing. The experiment was a randomized complete block design with three replications. At 21 days after planting (DAP), 25 seedlings per plot were removed from arbitrary $30-\mathrm{cm}$ sections of row, placed in reclosable plastic bags, placed on ice, returned to the laboratory, and refrigerated until processed. Seedlings were washed under running tap water to remove soil. The number of nodes and plant weights were recorded for all plants. Root or hypocotyl discoloration and galling associated with the root-knot nematode was rated by using the scales described previously. Roots after disease evaluation were rinsed, disinfested, and plated on the amended TB-CEN medium as described previously. Percent isolation and colonization were recorded as described previously.

Statistics. Statistical analyses were done by the appropriate statistical design using the GLM procedure with SAS (SAS Institute Inc., Cary, NC). The artificially infested experiment examining treatment effect in the presence or absence of $T$. $b a$ sicola and $M$. incognita was analyzed by infestation treatment (main plot). Root discoloration, colonization, and root galling were analyzed as mid-values for each category. Hypocotyl disease was analyzed as percentage of plants with lesions, a rating of three or four. Data from the multiple experiments were combined and analyzed by GLM with SAS when appropriate. Experiments were treated as random factors. Means were separated using Fisher's protected LSD at $P=0.05$. Orthogonal comparisons were used to examine the efficacy of product or rate on disease for some experiments.

\section{RESULTS}

Experiments in artificially infested soil. In the growth chamber, root and hypocotyl ratings caused by $T$. basicola were significantly reduced by both myclobutanil and acibenzolar- $S$-methyl compared to the nontreated seed (Table 1). T. basicola colonization also was significantly reduced by treatments containing either myclobutanil or acibenzolar- $S$-methyl or both compared to the nontreated seed. Isolation, the percentage of seedlings colonized by $T$. basicola, was lower in the treatments containing myclobutanil or myclobutanil with acibenzolar-S-methyl than in nontreated seed. In this study, myclobutanil alone or when combined with acibenzolar- $S$-methyl was more effective than acibenzolar- $S$ methyl alone in lowering hypocotyl ratings and root colonization. The number of nodes or plant fresh weight was not affected by the seed treatments in this study (data not shown).

In the greenhouse study using the four seed treatments, root discoloration was significantly reduced by all the treatments containing either myclobutanil or acibenzolar- $S$-methyl alone or in combination compared to the nontreated seed (Table 5). Hypocotyl lesions also were reduced in the treatments containing myclobutanil and myclobutanil with acibenzolar- $S$-methyl, but not acibenzolar-S-methyl alone, compared to the nontreated seed. Colonization of the root system by $T$. basicola was reduced by all treatments containing either myclobutanil or acibenzolar- $S$-methyl or a combination of both, relative to the nontreated seed treatment. Root discoloration was lower in the treatments containing myclobutanil or myclobutanil with acibenzolar-S-methyl than acibenzolar-S-methyl alone. Colonization was more significantly reduced by myclobutanil and acibenzolar$S$-methyl together than by either chemical alone. There were no differences among treatments in percent isolation of T. basicola. The number of nodes and plant wet

Table 4. Efficacy of seed treatments for early-season diseases in the field ${ }^{q}$

\begin{tabular}{|c|c|c|c|c|c|c|}
\hline Treatments & Rate (g a.i./100 kg) & $\begin{array}{l}\text { Root discoloration } \\
(\%)^{\mathrm{r}}\end{array}$ & $\begin{array}{l}\text { Hypocotyl } \\
\text { lesions }(\%)^{\mathrm{s}}\end{array}$ & Root galling ${ }^{t}$ & $\begin{array}{c}\text { Colonization } \\
(\%)^{\mathrm{u}}\end{array}$ & $\begin{array}{l}\text { Isolation } \\
(\%)\end{array}$ \\
\hline Nontreated $^{\mathrm{v}}$ & & $41.3 \mathrm{~A}^{\mathrm{w}}$ & $44.7 \mathrm{~A}$ & $25.7 \mathrm{~A}$ & $27.8 \mathrm{~A}$ & $88.0 \mathrm{~A}$ \\
\hline Myclobutanil $^{\mathrm{x}, \mathrm{y}}$ & 21 & $40.0 \mathrm{~A}$ & $2.6 \mathrm{~B}$ & $8.1 \mathrm{~A}$ & $13.7 \mathrm{~A}$ & $60.0 \mathrm{~A}$ \\
\hline Myclobutanil + abamectin ${ }^{\mathrm{x}, \mathrm{y}}$ & $42+208.04$ & $32.9 \mathrm{~A}$ & $2.6 \mathrm{~B}$ & $3.9 \mathrm{~A}$ & $13.4 \mathrm{~A}$ & $57.3 \mathrm{~A}$ \\
\hline $\begin{array}{l}\text { Myclobutanil }+ \text { abamectin }+ \\
\text { acibenzolar- } S \text {-methyl }{ }^{\mathrm{x}, \mathrm{y}}\end{array}$ & $21+208.04+0.6$ & $37.3 \mathrm{~A}$ & $4.0 \mathrm{~B}$ & $6.3 \mathrm{~A}$ & $15.9 \mathrm{~A}$ & $57.3 \mathrm{~A}$ \\
\hline $\begin{array}{l}\text { Myclobutanil }+ \text { abamectin }+ \\
\text { acibenzolar- } S \text {-methyl }{ }^{\mathrm{x}, \mathrm{y}}\end{array}$ & $21+208.04+1.0$ & $35.6 \mathrm{~A}$ & $4.0 \mathrm{~B}$ & $3.3 \mathrm{~A}$ & $14.1 \mathrm{~A}$ & $52.0 \mathrm{~A}$ \\
\hline $\begin{array}{l}\text { Myclobutanil }+ \text { abamectin }+ \\
\text { acibenzolar- } S \text {-methyl } 1^{\mathrm{x}, \mathrm{y}}\end{array}$ & $42+208.04+0.6$ & $38.7 \mathrm{~A}$ & $6.0 \mathrm{~B}$ & $4.0 \mathrm{~A}$ & $11.4 \mathrm{~A}$ & $62.6 \mathrm{~A}$ \\
\hline $\begin{array}{l}\text { Myclobutanil }+ \text { abamectin }+ \\
\text { acibenzolar- } S \text {-methyl }{ }^{\mathrm{x}, \mathrm{y}}\end{array}$ & $42+208.04+1.0$ & $33.1 \mathrm{~A}$ & $4.0 \mathrm{~B}$ & $3.0 \mathrm{~A}$ & $9.0 \mathrm{~A}$ & $53.3 \mathrm{~A}$ \\
\hline Myclobutanil + aldicarb ${ }^{\mathrm{x}, \mathrm{z}}$ & $21+840 \mathrm{~g}$ a.i. $/ \mathrm{ha}$ & $37.9 \mathrm{~A}$ & $2.6 \mathrm{~B}$ & $0.33 \mathrm{~A}$ & $10.0 \mathrm{~A}$ & $52.0 \mathrm{~A}$ \\
\hline$P$ value & & 0.8863 & 0.0001 & 0.1038 & 0.1263 & 0.1608 \\
\hline
\end{tabular}

q Seedlings sampled 21 days after planting.

${ }^{\mathrm{r}}$ Root discoloration was assessed on a 0 to 10 scale, where $0=0 \%, 1=1-10 \%, 2=11-20 \%, 3=21-30 \%, 4=31-40 \%, 5=41-50 \%, 6=51-60 \%, 7=61$ $70 \%, 8=71-80 \%, 9=81-90 \%$, and $10=91-100 \%$ of the root system discolored. Analyses were conducted on mid-percentile values.

${ }^{\mathrm{s}}$ Hypocotyl discoloration was assessed on a 1 to 4 scale, where $1=$ healthy, $2=$ slight discoloration, $3=$ lesions, and $4=$ girdling lesions. Percentages of plants having hypocotyls lesions, ratings of 3 or 4 , were analyzed and presented.

${ }^{\mathrm{t}}$ Galling was assessed on a 1 to 6 scale, where $1=$ no galls, $2=1-2$ galls, $3=3-10$ galls, $4=11-30$ galls, $5=31-100$ galls, and $6=$ galls $\geq 100$. Analyses were conducted on mid-values.

${ }^{u}$ Colonization was assessed on a 0 to 10 scale, where $0=0 \%, 1=1-10 \%, 2=11-20 \%, 3=21-30 \%, 4=31-40 \%, 5=41-50 \%, 6=51-60 \%, 7=61-70 \%, 8=71-$ $80 \%, 9=81-90 \%$, and $10=91-100 \%$ of the root system having growth of $T$. basicola on the medium. Analyses were conducted on mid-percentile values.

${ }^{v}$ Seed treated with thiamethoxam $(471.56 \mathrm{~g}$ a.i./100 kg seed).

${ }^{w}$ Means in a column followed by a common letter are not significantly different, protected LSD, $(P \leq 0.05)$.

${ }^{x}$ Seed treated with azoxystrobin + fludioxonil + mefenoxam (Dynasty CST, $41.60 \mathrm{~g}$ a.i. $/ 100 \mathrm{~kg}$ seed).

${ }^{\mathrm{y}}$ Seed treated with thiamethoxam + mefenoxam + fludioxonil $(471.56+7.5+2.5 \mathrm{~g}$ a.i. $/ 100 \mathrm{~kg}$ seed $)$.

${ }^{\mathrm{z}}$ Seed treated with mefenoxam + fludioxonil $(7.5+2.5 \mathrm{~g}$ a.i. $/ 100 \mathrm{~kg}$ seed $)$. 
weights were not affected by any seed treatment (data not shown).

In soils artificially infested with $T$. basicola or $T$. basicola and $M$. incognita, azoxystrobin + fludioxonil + mefenoxam or abamectin had no effect on root or hypocotyl symptoms or colonization by $T$. basicola compared to nontreated seed (Tables 2 and 6). In the absence of $M$. incognita, root discoloration caused by $T$. basicola was reduced by the treatments containing myclobutanil or acibenzolar-Smethyl compared to the nontreated seed, except for the low and intermediate rates of acibenzolar- $S$-methyl in combination with abamectin (Table 2). Root discoloration also was reduced for myclobutanil with abamectin compared to abamectin alone, and root discoloration was reduced for the intermediate rate of acibenzolar- $S$ methyl compared to the seed treatment. All treatments containing myclobutanil significantly reduced the percentage of plants with hypocotyl lesions compared to the nontreated seed or the seed treatment with or without abamectin. T. basicola colonization was significantly reduced by myclobutanil and the high rates of acibenzolar- $S$-methyl compared to the nontreated seed. Colonization also was significantly reduced in the treatments containing myclobutanil with abamectin and the low and high rates of acibenzolar- $S$-methyl with abamectin compared to the abamectin control. Isolation of $T$. basicola was high and did not differ among treatments for

Table 5. Efficacy of myclobutanil and acibenzolar-S-methyl seed treatments on black root rot in artificially infested soils in the greenhouse ${ }^{\mathrm{v}}$

\begin{tabular}{|c|c|c|c|c|c|}
\hline Treatments & $\begin{array}{l}\text { Rate (g a.i. } / \\
100 \mathrm{~kg} \text { seed) }\end{array}$ & $\begin{array}{l}\text { Root discolor- } \\
\text { ation }(\%)^{\mathrm{w}}\end{array}$ & $\begin{array}{l}\text { Hypocotyl } \\
\text { lesions }(\%)^{\mathrm{x}}\end{array}$ & $\begin{array}{c}\text { Colonization } \\
(\%)^{\mathrm{y}}\end{array}$ & $\begin{array}{c}\text { Isolation } \\
(\%)\end{array}$ \\
\hline Nontreated & & $38.8 \mathrm{~A}^{\mathrm{z}}$ & $50.6 \mathrm{~A}$ & $82.1 \mathrm{~A}$ & $95.8 \mathrm{~A}$ \\
\hline Acib & 1 & $23.5 \mathrm{~B}$ & $30.0 \mathrm{AB}$ & $45.8 \mathrm{~B}$ & $82.1 \mathrm{~A}$ \\
\hline Myclobutanil & 21 & $6.0 \mathrm{C}$ & $9.5 \mathrm{~B}$ & $38.6 \mathrm{~B}$ & $86.2 \mathrm{~A}$ \\
\hline $\begin{array}{l}\text { Acibenzolar- } S \text {-methyl + } \\
\text { myclobutanil }\end{array}$ & $1+21$ & $3.9 \mathrm{C}$ & $2.7 \mathrm{~B}$ & $22.2 \mathrm{C}$ & $55.5 \mathrm{~A}$ \\
\hline$P$ value & & $<0.0001$ & 0.0147 & $<0.0001$ & 0.0602 \\
\hline
\end{tabular}

${ }^{v}$ Experiments were conducted in a greenhouse with average temperatures of $25^{\circ} \mathrm{C}$ day and $19^{\circ} \mathrm{C}$ night and light intensity of $503 \mu \mathrm{mol} / \mathrm{m}^{2} / \mathrm{s}$.

${ }^{\text {w }}$ Root discoloration was assessed on a 0 to 10 scale, where $0=0 \%, 1=1-10 \%, 2=11-20 \%, 3=21$ $30 \%, 4=31-40 \%, 5=41-50 \%, 6=51-60 \%, 7=61-70 \%, 8=71-80 \%, 9=81-90 \%$, and $10=91-$ $100 \%$ of the root system discolored. Analyses were conducted on mid-percentile values.

${ }^{\mathrm{x}}$ Hypocotyl discoloration was assessed on a 1 to 4 scale, where $1=$ healthy, $2=$ slight discoloration, 3 $=$ lesions, and $4=$ girdling lesions. Percentages of plants having hypocotyl lesions, ratings of 3 or 4 , were analyzed and presented.

${ }^{y}$ Colonization was assessed on a 0 to 10 scale, where $0=0 \%, 1=1-10 \%, 2=11-20 \%, 3=21-30 \%, 4$ $=31-40 \%, 5=41-50 \%, 6=51-60 \%, 7=61-70 \%, 8=71-80 \%, 9=81-90 \%$, and $10=91-100 \%$ of the root system having growth of $T$. basicola on the medium. Analyses were conducted on mid-percentile values.

${ }^{\mathrm{z}}$ Combined data from two experiments. Means in a column followed by a common letter are not significantly different, protected LSD $(P \leq 0.05)$.

this study. In the presence of $T$. basicola, number of nodes and plant fresh weight were not affected by any of the seed treatments (data not shown).

In the presence of both $M$. incognita and $T$. basicola, only myclobutanil with abamectin significantly reduced root discoloration compared to the nontreated seed or abamectin (Table 6). Myclobutanil and the intermediate rate of acibenzolar- $S$ methyl without abamectin reduced root disease compared to the seed treatment azoxystrobin + fludioxomil + mefenoxam. Root discoloration was not affected by different rates of acibenzolar- $S$-methyl. The percentage of plants with hypocotyl lesions did not differ among treatments. Colonization of $T$. basicola in the presence of $M$. incognita was significantly reduced by the combination of myclobutanil and abamectin compared to myclobutanil alone. The treatments containing the intermediate rate of acibenzolar- $S$-methyl or low rate of acibenzolar- $S$-methyl with abamectin also reduced colonization compared to the nontreated seed or either the custom fungicide or abamectin seed treatments. The isolation of $T$. basicola was high in this study, and no differences were observed among treatments compared to the nontreated seed. In the presence of $T$. basicola, galling by $M$. incognita was more reduced by some treatments containing abamectin than by comparable treatments without abamectin. The myclobutanil treatment had greater gall ratings than almost all other treatments. According to orthogonal contrasts, all treatments with abamectin had reduced galling compared to comparable treatments without abamectin $(P=0.000022)$. The number of nodes and plant wet weight were not affected by the seed treatments (data not shown).

Table 6. Efficacy of seed treatments on black root rot in soils artificially infested with Thielaviopsis basicola and Meloidogyne incognita

\begin{tabular}{|c|c|c|c|c|c|c|}
\hline Treatments $^{\mathbf{u}}$ & $\begin{array}{c}\text { Rate (g a.i. } / \\
100 \mathrm{~kg})\end{array}$ & $\begin{array}{c}\text { Root discoloration } \\
(\%)^{\mathbf{v}}\end{array}$ & $\begin{array}{c}\text { Hypocotyl } \\
\text { lesions }(\%)^{\mathrm{w}}\end{array}$ & $\begin{array}{c}\text { Colonization } \\
(\%)^{\mathrm{x}}\end{array}$ & $\begin{array}{c}\text { Isolation } \\
(\%)\end{array}$ & Gallingy \\
\hline Nontreated & $\ldots$ & $51.1 \mathrm{AB}^{\mathrm{z}}$ & $64.3 \mathrm{~A}$ & $83.3 \mathrm{~A}$ & $96.6 \mathrm{~A}$ & $5.3 \mathrm{BC}$ \\
\hline Seed treatment & & $55.9 \mathrm{~A}$ & $72.5 \mathrm{~A}$ & $89.6 \mathrm{~A}$ & $97.5 \mathrm{~A}$ & $4.8 \mathrm{BCD}$ \\
\hline Myclobutanil & 21 & $38.8 \mathrm{BC}$ & $34.2 \mathrm{~A}$ & $83.7 \mathrm{~A}$ & $99.9 \mathrm{~A}$ & $10.5 \mathrm{~A}$ \\
\hline Acibenzolar-S-methyl & 0.3 & $46.2 \mathrm{AB}$ & $50.0 \mathrm{~A}$ & $85.2 \mathrm{~A}$ & $100.0 \mathrm{~A}$ & $7.4 \mathrm{AB}$ \\
\hline Acibenzolar-S-methyl & 0.6 & $39.6 \mathrm{BC}$ & $42.8 \mathrm{~A}$ & $61.1 \mathrm{BC}$ & $86.6 \mathrm{~A}$ & $3.9 \mathrm{BCD}$ \\
\hline Acibenzolar-S-methyl & 0.9 & $48.8 \mathrm{AB}$ & $35.0 \mathrm{~A}$ & $76.3 \mathrm{ABC}$ & $97.5 \mathrm{~A}$ & $5.9 \mathrm{C}$ \\
\hline Abamectin + myclobutanil & $208.04+21$ & $27.8 \mathrm{C}$ & $32.5 \mathrm{~A}$ & $61.5 \mathrm{BC}$ & $100.0 \mathrm{~A}$ & $0.9 \mathrm{D}$ \\
\hline Abamectin + acibenzolar- $S$-methyl & $208.04+0.3$ & $42.5 \mathrm{~B}$ & $50.0 \mathrm{~A}$ & $57.9 \mathrm{C}$ & $97.5 \mathrm{~A}$ & $2.2 \mathrm{CD}$ \\
\hline Abamectin + acibenzolar- $S$-methyl & $208.04+0.6$ & $43.3 \mathrm{AB}$ & $48.7 \mathrm{~A}$ & $76.9 \mathrm{AB}$ & $100.0 \mathrm{~A}$ & $2.5 \mathrm{CD}$ \\
\hline Abamectin + acibenzolar- $S$-methyl & $208.04+0.9$ & $41.0 \mathrm{~B}$ & $42.5 \mathrm{~A}$ & $76.7 \mathrm{AB}$ & $97.9 \mathrm{~A}$ & $1.9 \mathrm{CD}$ \\
\hline Abamectin & 208.04 & $51.6 \mathrm{AB}$ & $60.3 \mathrm{~A}$ & $82.8 \mathrm{~A}$ & $99.9 \mathrm{~A}$ & $1.0 \mathrm{D}$ \\
\hline$P$ value & & 0.0062 & 0.1173 & 0.0065 & 0.4775 & 0.0005 \\
\hline
\end{tabular}

${ }^{\mathrm{t}}$ Experiments were conducted in a growth chamber with average temperatures of $24^{\circ} \mathrm{C}$ day and $15^{\circ} \mathrm{C}$ night and light intensity of $207 \mu \mathrm{mol} / \mathrm{m}^{2} / \mathrm{s}$.

u All seed treated with azoxystrobin + fludioxonil + mefenoxam (Dynasty CST, $41.60 \mathrm{~g}$ a.i./100 kg seed), except nontreated.

${ }^{\mathrm{V}}$ Root discoloration was assessed on a 0 to 10 scale, where $0=0 \%, 1=1-10 \%, 2=11-20 \%, 3=21-30 \%, 4=31-40 \%, 5=41-50 \%, 6=51-60 \%, 7=61$ $70 \%, 8=71-80 \%, 9=81-90 \%$, and $10=91-100 \%$ of the root system discolored. Analyses were conducted on mid-percentile values.

${ }^{\text {w }}$ Hypocotyl discoloration was assessed on a 1 to 4 scale, where $1=$ healthy, $2=$ slight discoloration, $3=$ lesions, and $4=$ girdling lesions. Percentages of plants having hypocotyls lesions, ratings of 3 or 4 , were analyzed and presented.

$x$ Colonization was assessed by use of 0 to 10 scale, where $0=0 \%, 1=1-10 \%, 2=11-20 \%, 3=21-30 \%, 4=31-40 \%, 5=41-50 \%, 6=51-60 \%, 7=61-70 \%$, $8=71-80 \%, 9=81-90 \%$, and $10=91-100 \%$ of the root system having growth of T. basicola on the medium. Analyses were conducted on mid-percentile values.

y Galling was assessed by a 1 to 6 scale, where $1=$ no galls, $2=1-2$ galls, $3=3-10$ galls, $4=11-30$ galls, $5=31-100$ galls, and $6=$ galls $\geq 100$. Analyses were conducted on mid-values.

${ }^{\mathrm{z}}$ Combined data from two experiments. Means in a column followed by a common letter are not significantly different, protected LSD $(P \leq 0.05)$. 
According to orthogonal contrasts, treatments containing myclobutanil significantly decreased root discoloration caused by $T$. basicola both in the presence and in the absence of $M$. incognita, compared to treatments without these chemicals. In the presence of only $T$. basicola, treatments containing myclobutanil had an estimated mean difference of 23.6 from the comparable treatments without myclobutanil $(P=0.0001)$. In the presence of both pathogens, treatments containing myclobutanil had an estimated mean difference of 20.1 from the comparable treatments without myclobutanil $(P=0.0031)$. In the presence of only $T$. basicola, treatments containing acibenzolar- $S$-methyl did not reduce root discoloration. However, in the presence of both pathogens, root discoloration was reduced for treatments containing acibenzolar- $S$-methyl compared to comparable treatments without acibenzolar- $S$ methyl $(P=0.0279)$. However, no differences were found for different rates of acibenzolar- $S$-methyl for root discoloration according to orthogonal contrasts.

Results from orthogonal contrasts also indicated that treatments containing myclobutanil reduced hypocotyl lesions caused by $T$. basicola in the presence or in the absence of $M$. incognita, compared to treatments without myclobutanil. In the presence of only $T$. basicola, treatments containing myclobutanil had an estimated mean difference of 41.8 from the comparable treatments without myclobutanil $(P=$ 0.00028 ). In the presence of both pathogens, treatments containing myclobutanil had an estimated mean difference of 32.8 from the comparable treatments without myclobutanil $(P=0.0030)$. In the presence of only $T$. basicola, treatments containing acibenzolar-S-methyl did not affect the development of hypocotyl lesions. How- ever, in the presence of both pathogens, treatments containing acibenzolar- $S$ methyl reduced hypocotyl lesions compared to comparable treatments without acibenzolar- $S$-methyl $(P=0.0151)$. Different rates of acibenzolar- $S$-methyl did not differ for hypocotyl lesions according to orthogonal contrasts.

In the absence of $M$. incognita, treatments containing myclobutanil reduced colonization of the seedlings by $T$. basicola compared to comparable treatments without myclobutanil $(P=0.0009)$. However, in the presence of both pathogens, treatments containing myclobutanil did not significantly reduce colonization from the comparable treatments without myclobutanil $(P=0.0587)$. In the presence of only T. basicola, treatments containing acibenzolar- $S$-methyl did not reduce colonization $(P=0.0529)$, but in the presence of both pathogens, treatments containing acibenzolar- $S$-methyl did reduce colonization from the comparable treatments without acibenzolar- $S$-methyl $(P=0.0084)$.

In the experiments not infested with either pathogen, no galling or seedling disease was observed, indicating the pasteurization treatment was effective in eliminating the soilborne pathogens present. In noninfested soil, number of nodes and plant wet weight were not affected by the seed treatments, indicating that there was no phytotoxicity (data not shown). In the presence of only $M$. incognita, treatments containing abamectin significantly reduced root galling, 16.5 galls per root system, compared to treatments without abamectin, using orthogonal contrasts $(P=$ 0.000020).

Naturally infested soil experiments. In naturally infested soil from near St. Charles with a low $T$. basicola population (24 CFU/g soil) and in the presence of reniform nematode $\left(32,000 / 500 \mathrm{~cm}^{3}\right.$ soil), there was a treatment by experiment interaction for root discoloration, and experiments are presented separately (Table 3 ). Myclobutanil reduced root discoloration in experiment 1 at the low rate and in experiment 2 at the high rate compared to the base seed treatment. When myclobutanil was combined with acibenzolar-S-methyl, root discoloration was consistently reduced, except for the low rate of myclobutanil with the high rate of acibenzolar- $S$ methyl in experiment 1. Myclobutanil, when used at high rate in combination with the high rate of acibenzolar- $S$-methyl, provided better control of root discoloration than myclobutanil at the low rate with or without acibenzolar-S-methyl for some treatments. Hypocotyl ratings also were reduced by the treatments containing myclobutanil or myclobutanil with acibenzolar- $S$-methyl compared to the base seed treatment, except for the treatment containing the low rates of myclobutanil and acibenzolar- $S$-methyl. No differences were detected in number of nodes. A significant reduction in colonization was provided by all the treatments containing myclobutanil or myclobutanil with acibenzolar- $S$ methyl, except for the treatment containing the high rate of myclobutanil with abamectin. Myclobutanil, when used at the high rate in combination with the high rate of acibenzolar- $S$-methyl, provided the greatest reduction in colonization of $T$. basicola compared to all other treatments. Percent isolation of T. basicola also was reduced by the high rate of myclobutanil in combination with the high rate of acibenzolar- $S$ methyl.

In naturally infested soil collected in the fall from near Trumann with an intermediate $T$. basicola population (68 CFU/g soil), root and hypocotyl ratings were signifi-

Table 7. Efficacy of seed treatments for the control of black root rot in soil naturally infested with intermediate Thielaviopsis basicola populations

\begin{tabular}{|c|c|c|c|c|c|c|}
\hline Treatments & $\begin{array}{c}\text { Rate } \\
\text { (g a.i./100 kg) }\end{array}$ & $\begin{array}{c}\text { Root discoloration } \\
(\%)^{\mathrm{u}}\end{array}$ & $\begin{array}{l}\text { Hypocotyl } \\
\text { lesions }(\%)^{\mathrm{v}}\end{array}$ & Nodes & $\begin{array}{c}\text { Colonization } \\
(\%)^{\mathrm{w}}\end{array}$ & $\begin{array}{l}\text { Isolation } \\
(\%)\end{array}$ \\
\hline Base seed treatment ${ }^{\mathrm{x}}$ & & $75.1 \mathrm{~A}^{\mathrm{y}}$ & $92.5 \mathrm{~A}$ & $1.7 \mathrm{~B}$ & $95.5 \mathrm{~A}$ & $100 \mathrm{~A}$ \\
\hline Myclobutanil ${ }^{\mathrm{X}, \mathrm{Z}}$ & 21 & $51.4 \mathrm{~B}$ & $44.1 \mathrm{~B}$ & $1.9 \mathrm{AB}$ & $81.6 \mathrm{BC}$ & $100 \mathrm{~A}$ \\
\hline Myclobutanil + abamectin ${ }^{\mathrm{x}, \mathrm{z}}$ & $42+208.04$ & $50.7 \mathrm{~B}$ & $48.5 \mathrm{~B}$ & $2.0 \mathrm{~A}$ & $88.0 \mathrm{AB}$ & $100 \mathrm{~A}$ \\
\hline $\begin{array}{l}\text { Myclobutanil }+ \text { abamectin }+ \\
\text { acibenzolar- } S \text {-methyl }{ }^{\mathrm{x}, \mathrm{z}}\end{array}$ & $21+208.04+0.6$ & $49.7 \mathrm{~B}$ & $45.1 \mathrm{~B}$ & $2.0 \mathrm{~A}$ & $88.1 \mathrm{AB}$ & $100 \mathrm{~A}$ \\
\hline $\begin{array}{l}\text { Myclobutanil + abamectin + } \\
\text { acibenzolar- } S \text {-methyl }{ }^{\mathrm{x}, \mathrm{z}}\end{array}$ & $21+208.04+1.0$ & $49.4 \mathrm{~B}$ & $67.3 \mathrm{~B}$ & $2.0 \mathrm{~A}$ & $76.3 \mathrm{C}$ & $100 \mathrm{~A}$ \\
\hline $\begin{array}{l}\text { Myclobutanil + abamectin }+ \\
\text { acibenzolar- } S \text {-methyl }{ }^{x, z}\end{array}$ & $42+208.04+1.0$ & $41.7 \mathrm{~B}$ & $49.5 \mathrm{~B}$ & $1.8 \mathrm{AB}$ & $75.0 \mathrm{C}$ & $100 \mathrm{~A}$ \\
\hline$P$ value & & 0.0004 & 0.0019 & 0.0359 & $<0.0001$ & \\
\hline
\end{tabular}

${ }^{\mathrm{t}}$ Soil had a population of $T$. basicola of $68 \mathrm{CFU} / \mathrm{g}$ soil. Experiments were conducted in a growth chamber with average temperatures of $24^{\circ} \mathrm{C}$ day and $15^{\circ} \mathrm{C}$ night and light intensity of $207 \mu \mathrm{mol} / \mathrm{m}^{2} / \mathrm{s}$.

u Root discoloration was assessed on a 0 to 10 scale, where $0=0 \%, 1=1-10 \%, 2=11-20 \%, 3=21-30 \%, 4=31-40 \%, 5=41-50 \%, 6=51-60 \%, 7=61$ $70 \%, 8=71-80 \%, 9=81-90 \%$, and $10=91-100 \%$ of the root system discolored. Analyses were conducted on mid-percentile values.

${ }^{\mathrm{v}}$ Hypocotyl discoloration was assessed on a 1 to 4 scale, where $1=$ healthy, $2=$ slight discoloration, $3=$ lesions, and $4=$ girdling lesions. Percentages of plants having hypocotyl lesions, ratings of 3 or 4 , was analyzed and presented.

${ }^{\mathrm{w}}$ Colonization was assessed by a 0 to 10 scale, where $0=0 \%, 1=1-10 \%, 2=11-20 \%, 3=21-30 \%, 4=31-40 \%, 5=41-50 \%, 6=51-60 \%, 7=61-70 \%, 8=$ $71-80 \%, 9=81-90 \%$, and $10=91-100 \%$ of the root system having growth of T. basicola on the medium. Analyses were conducted on mid-percentile values.

${ }^{\mathrm{x}}$ Seed treated with thiamethoxam + mefenoxam + fludioxonil $(471.56+7.5+2.5 \mathrm{~g}$ a.i. $/ 100 \mathrm{~kg}$ seed $)$.

y Combined data from two experiments. Means in a column followed by a common letter are not significantly different, protected LSD $(P \leq 0.05)$.

${ }^{\mathrm{z}}$ Seed treated with azoxystrobin + fludioxonil + mefenoxam (Dynasty CST, $41.60 \mathrm{~g}$ a.i. $/ 100 \mathrm{~kg}$ seed). 
cantly reduced by all treatments containing myclobutanil or myclobutanil with acibenzolar-S-methyl compared to the base seed treatment (Table 7). Plant development (number of nodes) was improved with the treatments containing myclobutanil or myclobutanil with acibenzolar- $S$-methyl compared to the seed treatment, except for the treatments containing the low rate of myclobutanil and high rate of myclobutanil with acibenzolar- $S$-methyl. Colonization of $T$. basicola was significantly reduced by the treatments containing myclobutanil or myclobutanil with acibenzolar-S-methyl compared to the base seed treatment (thiamethoxam + mefenoxam + fludioxonil), except for the treatments containing myclobutanil at the high rate and myclobutanil with acibenzolar- $S$-methyl at the low rates. Percent isolation of $T$. basicola was $100 \%$ for all treatments in this study.

For the naturally infested soil collected near Portland with a high T. basicola population (154 or $162 \mathrm{CFU} / \mathrm{g}$ soil) in the presence of the root-knot nematode (625 or $415 / 500 \mathrm{~cm}^{3}$ soil), root discoloration was significantly reduced by all treatments containing myclobutanil or myclobutanil with acibenzolar-S-methyl, compared to the base seed treatment (Table 8). The higher rate of myclobutanil with acibenzolar- $S$-methyl provided better control for root discoloration, except for the high rate of myclobutanil alone. Similarly, hypocotyl ratings were significantly decreased by the treatments containing myclobutanil or myclobutanil with acibenzolar- $S$ methyl, compared to the base seed treatment, except for the treatment containing low rate of myclobutanil with the high rate of acibenzolar- $S$-methyl. No differences in the number of nodes were detected among treatments. Experiment 1 had greater mean root and hypocotyl ratings than experiment $2(P=0.05)$. There was an experiment by treatment interaction for colonization. For experiment 1 , colonization of $T$. basicola was significantly reduced by the high rate of myclobutanil in combination with high rate of acibenzolar- $S$-methyl relative to other treatments, except for the treatment with myclobutanil with acibenzolar- $S$ methyl (low rates). Myclobutanil at the high rate also reduced colonization compared to the control. In experiment 2, no treatments differed from the base seed treatment for colonization. Percent isolation of T. basicola was $98 \%$ or greater for all treatments in this experiment.

In the field study near Portland in 2007, root discoloration was not affected by seed treatments containing myclobutanil or myclobutanil with acibenzolar- $S$-methyl compared to no fungicide seed treatment (Table 4). However, hypocotyl ratings were significantly reduced by all treatments containing myclobutanil or myclobutanil with acibenzolar- $S$-methyl compared to no fungicide seed treatment. Number of nodes was not affected by any of these treatments (data not shown). Percent colonization and isolation of $T$. basicola did not differ among treatments. However, using orthogonal contrasts treatments containing myclobutanil or myclobutanil with acibenzolar-S-methyl significantly reduced percent colonization compared to no fungicide seed treatment $(P=0.0050)$. Similarly, treatments containing myclobutanil or myclobutanil with acibenzolar- $S$ methyl had an estimated mean difference for percent isolation of 31.6 from no fungicide seed treatment $(P=0.0051)$. There were no differences among treatments containing either abamectin or aldicarb for root galling caused by $M$. incognita. Or- thogonal contrast indicated that treatments containing either abamectin or aldicarb reduced root galling from the no fungicide seed treatment and fungicide seed treatment without nematicide $(P=0.0094)$.

\section{DISCUSSION}

Myclobutanil was effective in reducing root discoloration in experiments using artificially infested soil, and was more effective in experiments where soil populations were $60 \mathrm{CFU} / \mathrm{g}$ soil than $100 \mathrm{CFU} / \mathrm{g}$ soil. In experiments using naturally infested soils, myclobutanil was effective in reducing root discoloration at soil populations ranging from 24 to $162 \mathrm{CFU} / \mathrm{g}$ soil. Hypocotyl lesions also were reduced over a similar range of $T$. basicola populations. The high rate (42 $\mathrm{g}$ a.i./100 $\mathrm{kg}$ seed) of myclobutanil on the seed provided greater reduction in disease than the low rate $(21 \mathrm{~g}$ a.i./100 kg seed) in some experiments. Few differences in plant development were found in these experiments, which were terminated after 28 days. However, plant development had reached only one or two nodes under these environmental conditions, making differences in plant growth difficult to detect. Myclobutanil (6) and triadimenol (4) are triazole fungicides that have been previously shown to have some efficacy for the control of black root rot. Butler et al. (6) demonstrated in the greenhouse, with soils artificially infested with T. basicola, that rates of myclobutanil as low as $20 \mathrm{~g}$ a.i./100 kg seed significantly reduced root necrosis even at high rates of inoculum (300 to $400 \mathrm{CFU} / \mathrm{g}$ soil). Similarly, seed treatments containing triadimenol with thiram and metalaxyl greatly reduced root necrosis, primarily attributed to T. basicola, from 77 to $47 \%$ in controlled-environment experiments using

Table 8. Efficacy of seed treatments for the control of black root rot in soil naturally infested with high Thielaviopsis basicola populations ${ }^{t}$

\begin{tabular}{|c|c|c|c|c|c|c|c|}
\hline \multirow[b]{2}{*}{ Treatments } & \multirow{2}{*}{$\begin{array}{c}\text { Rate } \\
\text { (g a.i./100 kg) } \\
\end{array}$} & \multirow{2}{*}{$\begin{array}{l}\text { Root discoloration } \\
(\%)^{\mathrm{v}}\end{array}$} & \multirow{2}{*}{$\begin{array}{c}\text { Hypocotyl } \\
\text { lesions }(\%)^{\mathrm{w}}\end{array}$} & \multirow[b]{2}{*}{ Nodes } & \multicolumn{2}{|c|}{ Colonization $(\%)^{\mathrm{u}}$} & \multirow{2}{*}{$\begin{array}{c}\text { Isolation } \\
(\%)\end{array}$} \\
\hline & & & & & Exp. 1 & Exp. 2 & \\
\hline Base seed treatment ${ }^{\mathrm{x}}$ & & $88.4 \mathrm{~A}^{\mathrm{y}}$ & $93.3 \mathrm{~A}$ & $0.9 \mathrm{~A}$ & $95.9 \mathrm{~A}$ & $54.3 \mathrm{AB}$ & $100 \mathrm{~A}$ \\
\hline Myclobutanil $^{\mathrm{X}, \mathrm{Z}}$ & 21 & $67.2 \mathrm{BC}$ & $44.0 \mathrm{~B}$ & $1.0 \mathrm{~A}$ & $92.6 \mathrm{AB}$ & $33.8 \mathrm{~B}$ & $100 \mathrm{~A}$ \\
\hline Myclobutanil + abamectin ${ }^{\mathrm{x}, \mathrm{z}}$ & $42+208.04$ & $59.9 \mathrm{CD}$ & $40.3 \mathrm{~B}$ & $0.9 \mathrm{~A}$ & $85.9 \mathrm{BC}$ & $40.5 \mathrm{~B}$ & $98 \mathrm{~A}$ \\
\hline $\begin{array}{l}\text { Myclobutanil + abamectin+ } \\
\text { acibenzolar- } S \text {-methyl }{ }^{\mathrm{x}, \mathrm{z}}\end{array}$ & $21+208.04+0.6$ & $66.1 \mathrm{BC}$ & $50.7 \mathrm{~B}$ & $1.0 \mathrm{~A}$ & 83.6 CD & $41.3 \mathrm{~B}$ & $98 \mathrm{~A}$ \\
\hline $\begin{array}{l}\text { Myclobutanil + abamectin+ } \\
\text { acibenzolar- } S \text {-methyl }{ }^{\mathrm{x}, \mathrm{z}}\end{array}$ & $21+208.04+1.0$ & $72.5 \mathrm{~B}$ & $58.5 \mathrm{AB}$ & $0.9 \mathrm{~A}$ & $88.2 \mathrm{ABC}$ & $70.9 \mathrm{~A}$ & $100 \mathrm{~A}$ \\
\hline $\begin{array}{l}\text { Myclobutanil + abamectin+ } \\
\text { acibenzolar-S-methyl }{ }^{\mathrm{X}, \mathrm{z}}\end{array}$ & $42+208.04+1.0$ & $51.8 \mathrm{D}$ & $40.1 \mathrm{~B}$ & $0.9 \mathrm{~A}$ & $76.7 \mathrm{D}$ & $43.9 \mathrm{~B}$ & 99 A \\
\hline$P$ value & & $<0.0001$ & $<0.0001$ & 0.76 & $<0.0001$ & 0.02 & 0.66 \\
\hline
\end{tabular}

${ }^{\mathrm{t}}$ Soil had a population of T. basicola of 154 or $162 \mathrm{CFU} / \mathrm{g}$ soil. Experiments were conducted in a growth chamber with average temperatures of $24^{\circ} \mathrm{C}$ day and $15^{\circ} \mathrm{C}$ night and light intensity of $207 \mu \mathrm{mol} / \mathrm{m}^{2} / \mathrm{s}$.

" Colonization was assessed on a 0 to 10 scale, where $0=0 \%, 1=1-10 \%, 2=11-20 \%, 3=21-30 \%, 4=31-40 \%, 5=41-50 \%, 6=51-60 \%, 7=61-70 \%, 8=$ $71-80 \%, 9=81-90 \%$, and $10=91-100 \%$ of the root system having growth of $T$. basicola on the medium. Analyses were conducted on mid-percentile values.

${ }^{\mathrm{v}}$ Root discoloration was assessed on a 0 to 10 scale, where $0=0 \%, 1=1-10 \%, 2=11-20 \%, 3=21-30 \%, 4=31-40 \%, 5=41-50 \%, 6=51-60 \%, 7=61-$ $70 \%, 8=71-80 \%, 9=81-90 \%$, and $10=91-100 \%$ of the root system discolored. Analyses were conducted on mid-percentile values.

${ }^{\text {w }}$ Hypocotyl discoloration was assessed on a 1 to 4 scale, where $1=$ healthy, $2=$ slight discoloration, $3=$ lesions, and $4=$ girdling lesions. Percentages of plants that had hypocotyl lesions, ratings of 3 or 4 , were analyzed and presented.

${ }^{x}$ Seed treated with thiamethoxam + mefenoxam + fludioxonil $(471.56+7.5+2.5 \mathrm{~g}$ a.i./100 kg seed).

${ }^{y}$ Combined data from two experiments, except when presented separately. Means in a column followed by a common letter are not significantly different, protected LSD $(P \leq 0.05)$.

${ }^{\mathrm{z}}$ Seed treated with azoxystrobin + fludioxonil + mefenoxam (Dynasty CST, $41.60 \mathrm{~g}$ a.i./100 kg seed). 
naturally infested soil (34). The other fungicides used in these studies, azoxystrobin, fludioxonil, and mefenoxam, did not show any efficacy against $T$. basicola .

Acibenzolar- $S$-methyl was effective in soil artificially infested with $T$. basicola using 60 or $100 \mathrm{CFU} / \mathrm{g}$ soil, except for the artificially infested experiment conducted in the absence of $M$. incognita at 100 $\mathrm{CFU} / \mathrm{g}$ soil. Rates of acibenzolar-S-methyl did not differ in efficacy. In a previous study, cottonseed soaked in solutions containing 25 or $50 \mu \mathrm{g}$ of acibenzolar- $S$ methyl $/ \mathrm{ml}$ distilled water for $12 \mathrm{~h}$ reduced the severity of black root rot in container and field experiments (21). Mondal et al. (21) reported that reductions in taproot discoloration for these acibenzolar- $S$ methyl treatments were generally 20 to $30 \%$. In experiments examining acibenzolar- $S$-methyl alone, reductions in discoloration of the root system ranged from 39 to $64 \%$ using soil populations of 60 chlamydospores/g soil and from 12 to $38 \%$ using soil populations of 100 chlamydospores/g soil, giving similar results to Mondal et al. (21). Allen (2) reported acibenzolar- $S$-methyl seed treatment, in the absence of sterol-inhibiting fungicides, appeared to be more effective under low disease pressure than under high disease pressure for field evaluations. In naturally infested experiments, acibenzolar- $S$-methyl was not evaluated separately, but as part of a seed treatment combination with myclobutanil to manage the seedling disease complex. In these studies, acibenzolar- $S$ methyl was shown to be effective over a range of soil populations of $T$. basicola in the presence or absence of nematodes. Based on the level and consistency of black root rot control, the use of triazole fungicides like myclobutanil is a more important component of a seed treatment formulation, but acibenzolar- $S$-methyl would enhance the level of control as part of the seed treatment mixture. In Australia, acibenzolar- $S$-methyl is being used alone for black root rot control in the seed treatment formulation.

Seedling diseases on cotton are caused by a number of pathogens contributing to the seedling disease complex, making it difficult to determine the importance of individual pathogens or the efficacy of different fungicides against specific pathogens in the field. Colonization by T. basicola was significantly reduced by myclobutanil or acibenzolar-S-methyl, indicating the reductions in seedling disease were due to reductions in T. basicola in naturally infested soils and not other pathogens in the seedling disease complex. In the field experiment, treatments containing either myclobutanil or myclobutanil with acibenzolar- $S$-methyl reduced the percent isolation of T. basicola by $36 \%$ compared to treatments without these chemicals. Thus, isolation of $T$. basicola on the semi-selective medium TB-CEN allowed the evaluation of the contribution of black root rot to seedling disease.

An additive effect for myclobutanil and acibenzolar- $S$-methyl was observed in both artificially and naturally infested soils for some experiments. In artificially infested experiments in the greenhouse study using four treatments, root colonization was lower in the treatment containing both myclobutanil and acibenzolar- $S$-methyl than with either chemical alone. When acibenzolar- $S$-methyl was combined with myclobutanil at the high rate $(1 \mathrm{~g}$ a.i./100 $\mathrm{kg}$ seed) in naturally infested soils, significant reductions in colonization were observed over myclobutanil alone at low (24 $\mathrm{CFU} / \mathrm{g}$ soil) and high (154 CFU/g) populations of $T$. basicola in some experiments. Similarly, an additive effect for survival of pepper plants from Phytophthora root and crown rot, caused by Phytophthora capsici, was reported under some environments when acibenzolar-S-methyl was used with mefenoxam (18). Additive effects from the use of acibenzolar- $S$-methyl with fungicides also have been reported for several foliar diseases including with trifloxistrobin for white rust on spinach (17), fenpropidin for powdery mildew on wheat (24), and a fungicide program using copper oxychloride, mancozeb, and iprodione with or without azoxystrobin for scab on passionfruit (35). Application of the SAR chemical inducer BABA (DL-3aminobutyric acid) also has been reported to have additive or synergistic effects with fungicides for the control of late blight on potato and tomato (5), downy mildew on cucumber (5) and tobacco (9), and powdery mildew on wheat, barley, and cucumber (9). However, in this study the acibenzolar-S-methyl was applied to the seed instead of the foliage or stems.

T. basicola interacts synergistically with $M$. incognita, the root-knot nematode, on cotton (29-31). In microplot studies, root necrosis was greater in the presence of $M$. incognita than in the absence $M$. incognita (31). In our studies, colonization of root systems by $T$. basicola in the presence of nematodes was higher than colonization of roots infected by $T$. basicola alone. Colonization of $T$. basicola in the presence of $M$. incognita was lower in the treatment containing myclobutanil with abamectin than myclobutanil alone, suggesting that root-knot nematode plays a role in black root rot development. Even though little galling or nematode damage was observed on seedlings after 28 days, research has shown that early nematode infection plays an important role in colonization of the vascular tissue by $T$. basicola (30). These results emphasize the importance of management of early-season nematode damage on cotton to limit seedling disease losses.

In this study, the efficacy of triazole fungicides and SAR chemical inducers was documented over a range of $T$. basicola populations by using artificially and naturally infested soils. Myclobutanil and acibenzolar-S-methyl appear promising for the control of black root rot. The efficacy for myclobutanil was demonstrated at rates used currently by seed companies. When myclobutanil was used at higher rates of application to the seed, it was more effective. Previous research measured only root discoloration and hypocotyl discoloration for disease evaluations. In the field or in naturally infested soils, root or hypocotyl discoloration may be caused by other pathogens or abiotic factors, complicating the interpretation of the importance of individual factors or efficacy of products against individual pathogens. Other indicators of black root rot severity, including colonization and incidence, were important in assessing black root rot as a result of the numerous pathogens in the seedling disease complex, giving a true indication of what portion of root or hypocotyl discoloration is associated with $T$. basicola.

\section{ACKNOWLEDGMENTS}

Published with the approval of the Director, Arkansas Experiment Station, Fayetteville. Partial funding support for this work was provided by Syngenta Crop Protection. The authors thank A. Mauromoustakos and E. E. Gbur for statistical assistance and S. A. Winters and R. J. Bateman for technical assistance.

\section{LITERATURE CITED}

1. Allen, S. J. 2001. Black root rot. Pages 16-17 in: Compendium of Cotton Diseases. T. L. Kirkpatrick and C. S. Rothrock, eds. American Phytopathological Society, St. Paul, MN.

2. Allen, S. J. 2008. Field evaluation of a seed treatment that induces resistance to Thielaviopsis basicola in cotton. In: Proc. World Cotton Res. Conf.-4. Lubbock, TX, September 1014, 2007. In press.

3. Arshad, M. A., Lowery, B., and Grossman, B. 1996. Physical tests for monitoring soil quality. Pages 123-141 in: Methods for Assessing Soil Quality. J. W. Doran and A. J. Jones, eds. Soil Sci. Soc. Am. Spec. Publ. 49. Soil Science Society of America, Madison, WI.

4. Arthur, K. S., Hairston, W. G., and Graham, C. T. 1991. Utilizing triadimenol as a cofungicide to enhance disease suppression of Rhizoctonia and Thielaviopsis in cotton stand establishment. Pages 169-172 in: Proc. 1991 Belt-wide Cotton Conf. D. J. Herber and D. A Richter, eds. National Cotton Council, Memphis, TN.

5. Baider, A., and Cohen, Y. 2003. Synergistic interaction between BABA and mancozeb in controlling Phytophthora infestans in potato and tomato and Pseudoperonospora cubensis in cucumber. Phytoparasitica 31:399-409.

6. Butler, L. D., Lawrence, D., and Becton, M. 1996. Nu-flow M: A safe new seed treatment fungicide for the control of cotton seedling disease caused by Thielaviopsis basicola and Rhizoctonia solani. Pages 268-269 in: Proc. 1996 Belt-wide Cotton Conf. National Cotton Council, Memphis, TN.

7. Byrd, D. W., Jr., Barker, K. R., Ferris, H., Nusbaum, C. J., Griffin, W. E., Small, R. H., and Stone, C. A. 1976. Two semi-automatic elutriators for extracting nematodes and certain fungi from soil. J. Nematol. 8:206-212.

8. Candole, B. L., and Rothrock, C. S. 1997. Characterization of the suppressiveness of hairy vetch-amended soils to Thielaviopsis basicola. Phytopathology 87:197-202.

9. Cohen, Y. R. 2002. $\beta$-Aminobutyric acid- 
induced resistance against plant pathogens. Plant Dis. 86:448-457.

10. Gomaa, N. M. 2004. Studies on some alternative methods for management of cotton seedling disease complex. Ph.D. thesis. Cairo University-Fayoum Branch.

11. Hillocks, R. J. 1992. Cotton diseases. C.A.B. International, Wallingford, UK

12. Holtz, B. A., and Weinhold, A. R. 1994. Thielaviopsis basicola in San Joaquin Valley soils and the relationship between inoculum density and disease severity of cotton seedlings. Plant Dis. 78:986-990.

13. Hussey, R. S., and Barker, K. R. 1973. A comparison of methods of collecting inocula of Meloidogyne spp., including a new technique. Plant Dis. Rep. 57:1025-1028.

14. Jenkins, W. R. 1964. A rapid centrifugalflotation technique for separating nematodes from soil. Plant Dis. Rep. 48:692.

15. King, C. J., and Barker, H. D. 1939. An internal collar rot on cotton. Phytopathology 29:751.

16. King, C. J., and Presley, J. T. 1942. A root rot of cotton caused by Thielaviopsis basicola. Phytopathology 32:752-761.

17. Leskovar, D. I., and Kolenda, K. 2002. Strobilurin + acibenzolar-S-methyl controls white rust without inducing leaf chlorosis in spinach. Ann. Appl. Biol. 140:171-175.

18. Matheron, M. E., and Porchas, M. 2002. Suppression of Phytopthora root and crown rot on pepper plants treated with acibenzolar- $S$ methyl. Plant Dis. 86:292-297.

19. Mathre, D. E., Ravenscorf, A. V., and Garber, R. H. 1966. The role of Thielaviopsis basicola as a primary cause of yield reduction in cotton in California. Phytopathology 56:1213-1216.
20. Mauk, P. A., and Hine, R. B. 1988. Infection, colonization of Gossypium hirsutum and $G$. barbadense, and development of black root rot caused by Thielaviopsis basicola. Phytopathology 78:1662-1667.

21. Mondal, A. H., Nehl, D. B., and Allen, S. J. 2005. Acibenzolar-S-methyl induces systemic resistance in cotton against black root rot caused by Thielaviopsis basicola. Australas. Plant Pathol. 34:499-507.

22. Monfort, W. S., Kirkpatrick, T. L., and Rothrock, C. S. 2006. Effects of nocturnal soil temperatures and Meloidogyne incognita densities on cotton seedling growth and the interaction with Thielaviopsis basicola. Plant Dis. 90:519-522.

23. Nehl, D. B., Allen, S. J., Mondal, A. H., and Lonergan, P. A. 2004. Black root rot: A pandemic in Australian cotton. Australas. Plant Pathol. 33:87-95.

24. Oostendorp, M., Kunz, W., Dietrich, B., and Staub, T. 2001. Induced resistance in plants by chemicals. Eur. J. Plant Pathol. 107:19-28.

25. Rothrock, C. S. 1992. Influence of soil temperature, water, and texture on Thielaviopsis basicola and black root rot of cotton. Phytopathology 82:1202-1206.

26. Rothrock, C. S. 1999. Thielaviopsis basicola. In: Crop Protection Compendium. C.A.B. International, Wallingford, UK.

27. Sherbakoff, C. D. 1940. An occurrence on cotton of black root rot caused by Thielaviopsis basicola. Proc. Cotton Dis. Counc. 5:4.

28. Specht, L. H., and Griffin, G. J. 1985. A selective medium for enumerating low populations of Thielaviopsis basicola. Can. J. Plant Pathol. 7:438-441

29. Walker, N. R., Kirkpatrick, T. L., and
Rothrock, C. S. 1998. The interaction between the root-knot nematode (Meloidogyne incognita) and black root rot (Thielaviopsis basicola) on cotton (Gossypium hirsutum). J. Nematol. 30:415-422.

30. Walker, N. R., Kirkpatrick, T. L., and Rothrock, C. S. 1999. Effect of temperature on and histopathology of the interaction between Meloidogyne incognita and Thielaviopsis basicola on cotton. Phytopathology 89:613-617.

31. Walker, N. R., Kirkpatrick, T. L., and Rothrock, C. S. 2000. Influence of Meloi dogyne incognita and Thielaviopsis basicola populations on early-season disease development and cotton growth. Plant Dis. 84:449453.

32. Wang, H., and Davis, R. M. 1997. Susceptibility of selected cotton cultivars to seedling disease pathogens and benefits of chemical seed treatments. Plant Dis. 81:1085-1088.

33. Wheeler, T. A., and Gannaway, J. R. 1998. Effects of cotton pathogens on disease symptoms and yield of cotton varieties in large plot field trials. Pages 165-168 in: Proc. 1998 Beltwide Cotton Conf. P. Dugger and D. A. Rochter, eds. National Cotton Council, Memphis, TN.

34. Wheeler, T. A., Gannaway, J. R., and Keating, K. 1999. Identification of resistance to Thielaviopsis basicola in diploid cotton. Plant Dis 83:831-833.

35. Willingham, S. L., Pegg, K. G., Langdon, P. W. B., Cooke, A. W., Peasley, D., and McLennan, R. 2002. Combinations of strobilurin fungicides and acibenzolar (Bion) to reduce scab on passionfruit caused by Cladosporium oxysporum. Australas. Plant Pathol. 31:333-336. 